\title{
Physiographic and Soil Mapping of Qena and El-Qarn Wadis by Using Remote Sensing and GIS
}

\author{
M. M. Ibrahim, M. A. Wahab*, R. R. Ali", A. A. EL-Baroudy and A. A. Hussein* \\ Soil and Water Dept., Faculty of Agric., Tanta Univ. and "Soils and Water Use Dept., \\ National Research Centre (NRC), Egypt
}

\begin{abstract}
THE MAIN objective of the current study is to use remote sensing data and GIS to map the physiography and soils of Wadi Qena-Wadi El-Qarn area. To fulfill this objective the Landsat-8 image acquired during 2015 and Shuttle Radar Topography Mission (SRTM) data employed. The preliminary physiographic map was produced and checked during fieldwork. A total of 20 soil profiles were collected and analyzed then the data were used to classify the investigated soils to sub-great group level. The correlation between physiography and soils was achieved. The results indicated that the main physiographic units in the area include Crest, Upland, Pediplain, Bajada and Wadis. These units are occupied by two sub-great groups , i.e. Typic torripsamments and Typic quartzipsamments.
\end{abstract}

Keywords: Landforms, Soils, GIS, Remote sensing, Egypt

\section{Introduction}

The science of remote sensing consists of the analysis and interpretation of measurements of electromagnetic radiation that is reflected from or emitted by a target and observed by an observer or instrument that is not in direct contact with the target (Mather and Koch, 2011). On the other hand GIS handles geographic data, which include both spatial and attribute data that describe geographic features. The basic functions of GIS include data input, storage, processing, and output. In addition, GIS has been called or defined as an enabling technology because of the breadth of uses in the following disciplines as a tool (Weng, 2010). Remote sensing data can be used to extract thematic and metric information, making it ready for input into GIS (Reddy, 2008). Terrain mapping is the process of dividing the landscape into polygons based on a terrain classification system. The terrain map shows the distribution of deposits and related landforms on the earth's surface. It also provides information about present day geomorphological processes. A terrain mapping is important for development in terms of economy and improvement of life conditions. It is done at different levels, with different techniques and corresponding results of different quality (Lazaridou and Patmios, 2002).Accurate characterization of morphology is critical to many studies in the field of geomorphology, particularly those dealing with changes over time. Digital Elevation Models (DEMs) are commonly used to represent morphology in three dimensions. The quality of the DEM is largely a function of the accuracy of individual survey points, field survey strategy, and the method of interpolation (Heritage, 2009)

The main objective of the current study is to integrate land surveying, remote sensing data with GIS techniques to produce accurate landform and soil maps of Wadi Qena-Wadi El-Qarn area.

\section{Materials and Methods}

Study area

The studied area is bounded by longitudes $3242^{\circ}$ and $33^{\circ} 00^{\prime}$ east and latitudes $25^{\circ} 53^{\prime}$ and $26^{\circ} 22^{\prime}$ north as shown in Fig. 1. This area is located in the Eastern Desert, east of River Nile. The investigated area comprises two main wadis named Qena and El-Qarn Wadis. The area is built lithologically of rock units of the Precambrian, Cretaceous, Pliocene, Eocene, Oligocene, Miocene, Pliocene and Quaternary times (Aggor, 1997). The rocks are covered by friable sediments that range in age from Late Cretaceous to Holocene (Abd El-Gaffar, 1997). The main geomorphological units of this are: mouth hills; wadi plains; terraces and hummocks (Hassan, 1984). 


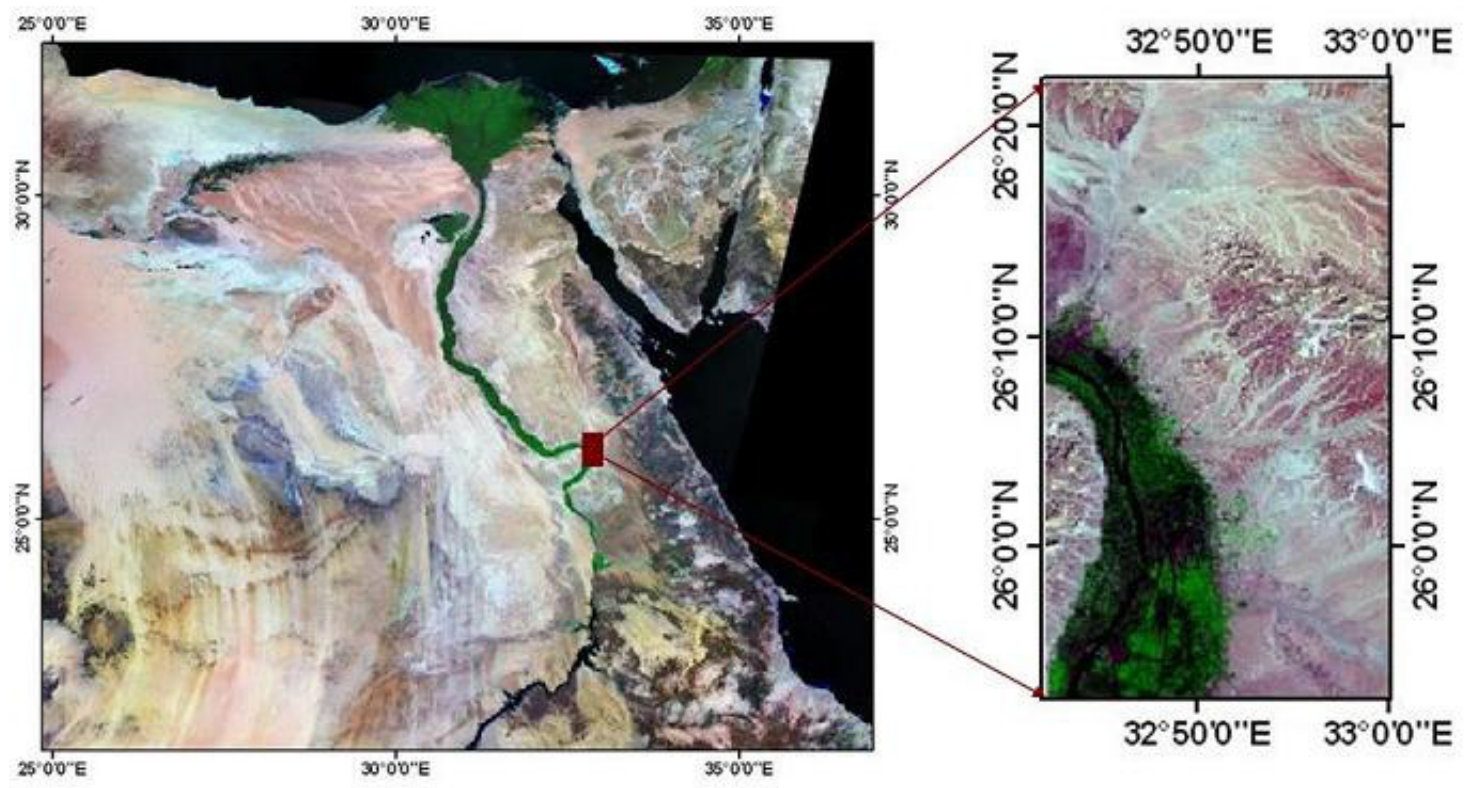

Fig. 1. Location Map of the studied area

\section{:Satellite data processing}

Landsat-8 image acquired during the year 2015 (pass 175/row 42) was used in this study. To improve the contrast and enhancing the edges, the image was stretched using linear $2 \%$, smoothly filtered, and their histograms were matched according to Lillesand and Kiefer (2007). The atmospheric, radiometric and geometric corrections were done using ENVI 4.7 (ITT, 2009). The Digital Elevation Model (DEM) of the study area was extracted from the Shuttle Radar Topography Mission (SRTM). This data could be combined with multispectral images to realize better view of the landscape.

\section{:Landform and soil mapping}

The Landsat ETM+ image and SRTM data were processed in ENVI 4.7 software to identify the different landforms and establish the soil database (Dobos et al., 2002 and Zinck \& Valenzuela, 1990). A semi detailed survey was carried out throughout the investigated area in order to gain an appreciation on soil patterns, landforms and the landscape characteristics. A total of 52 ground truth sites were studied in the field to check the different preliminary mapping units. A total of 20 soil profiles were observed and the morphological features were outlined according to FAO (2006). Then representative soil samples have been collected and prepared for laboratory analyses according to USDA (2004). The soils were classified to the sub great group level on the basis of the key to soil taxonomy (USDA, 2010). The correlations between physiographic and taxonomic units were Egypt. J. Soil Sci. 57, No. 2 ( 2017 ) carried out in order to produce the physiographic - soil map of the studied area (Elbersen\& Catalan, 1986). The obtained data from land survey and laboratory analyses were recorded in the attribute table of the landform map using Arc-GIS 9.2 software.

\section{Results and Discussion}

\section{Physiographic mapping}

The generated and validated physiographic map of the investigated area reveals that, the landscape is mainly consists of mountainous and dissected plateaus. The main landforms which constitute the landscape are Crest, Upland, Pediplain, Bajada and Wadi. Hence, according to the abovementioned geopedological approach the landscape relations separate most of the variation in the soils. Thus the soil pattern related to land forms can be extrapolated to universalized map units. The physiographic map legend and the area in feddan and percentage of each mapping unit of the studied are area are calculated and presented in Table 1. The obtained results are shown in Fig. 1 and comprise five main landforms named: Crest, Upland, Pediplain, Wadi and Bajada. The Crest landform covers an area of 23917.15 feddans and forms $8.17 \%$ of the total area. The Upland landform covers an area of 81482.58 feddans and forms $27.83 \%$ of the total area. The Pediplan landform covers an area of 68153.74 feddans and forms $23.28 \%$ of the total area. The Wadi landform covers an area of 102018.7 feddans and forms 34.85 $\%$ of the total area. The Bajada landform covers an area of 17193.20 feddans and forms $5.87 \%$ of the 
total area. The more valuable landforms for soil investigation are, Pediplain, Wadi bottom and Bajada which totally cover an area of 187365.64 feddans and form $64.0 \%$ of the total studied area. Thus, after excluding the crest and upland landforms areas, the proportion of the investigated landforms will be changed to $9.18 \%$ for Bajada, 36.38 for Pediplain and 54.44 for Wadi.

TABLE 1. Physiographic legend and areas of different mapping units

\begin{tabular}{|c|c|c|c|c|c|c|c|}
\hline \multirow{2}{*}{$\begin{array}{l}\text { Morphogenetic } \\
\text { environment }\end{array}$} & \multirow[b]{2}{*}{ Landscape } & \multirow{2}{*}{$\begin{array}{l}\text { Lithology / } \\
\text { Facies }\end{array}$} & \multirow[b]{2}{*}{ Relief/Molding } & \multirow[b]{2}{*}{ Landform } & \multirow[b]{2}{*}{ Symbol } & \multicolumn{2}{|c|}{ Area } \\
\hline & & & & & & Feddans & $\%$ \\
\hline \multirow{5}{*}{$\begin{array}{l}\text { Erosional and } \\
\text { depositional }\end{array}$} & \multirow{5}{*}{$\begin{array}{l}\text { Mountainous and } \\
\text { Dissected plateaus }\end{array}$} & \multirow{5}{*}{$\begin{array}{c}\text { Limestone and } \\
\text { sandstone Marine } \\
\text { and fluvial origin }\end{array}$} & \multirow[b]{2}{*}{ Plateaus P1 } & Crest & P11 & 23917.15 & 8.17 \\
\hline & & & & Upland & $\mathrm{P} 12$ & 81482.58 & 27.83 \\
\hline & & & \multirow{3}{*}{ Wadis P2 } & Pediplain & P21 & 68153.74 & 23.28 \\
\hline & & & & Bajada & $\mathrm{P} 22$ & 17193.20 & 5.87 \\
\hline & & & & Wadi & $\mathrm{P} 23$ & 102018.7 & 34.3 \\
\hline
\end{tabular}
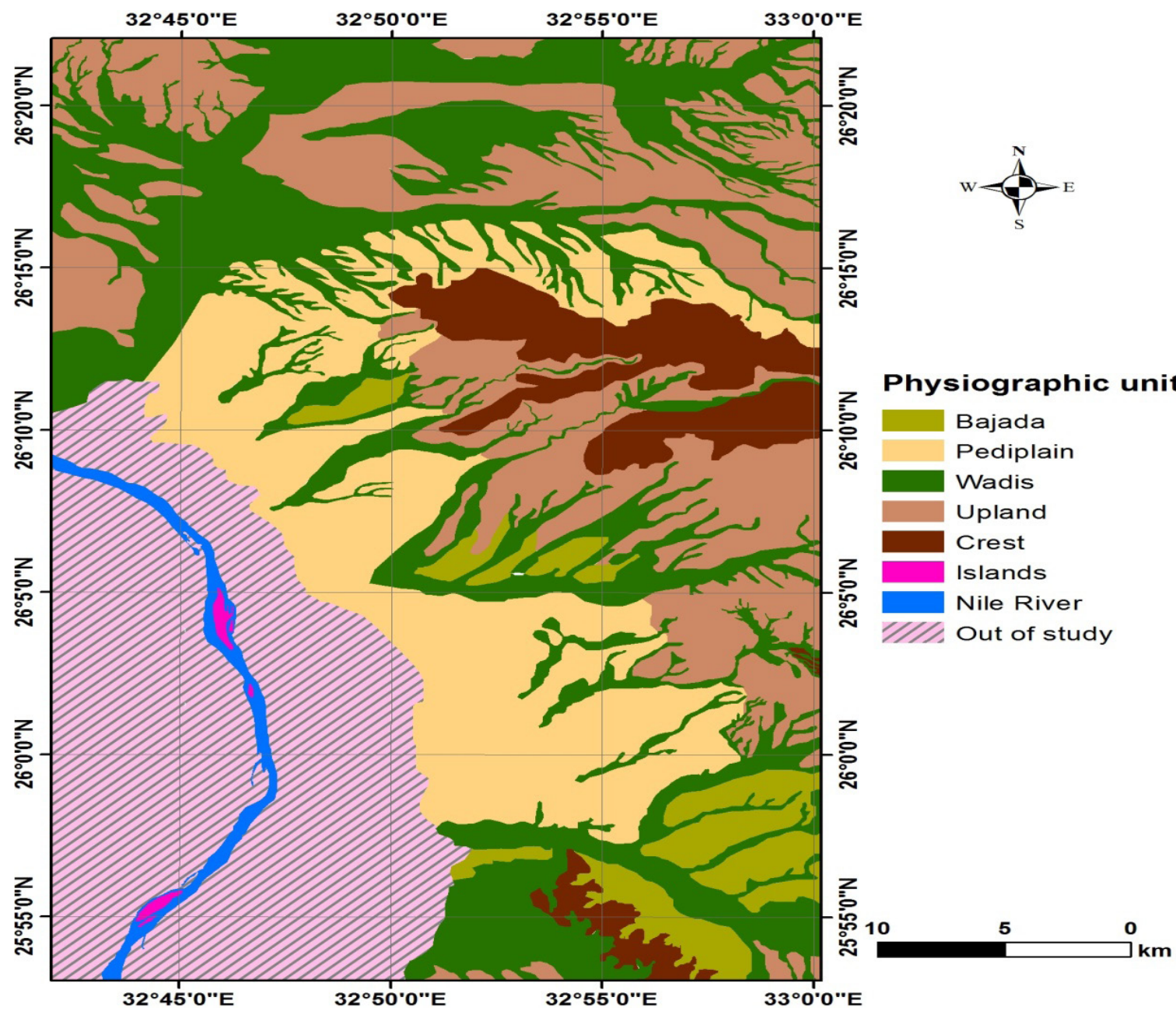

Fig. 2. Physiographic map of the investigated area

Physiography and soils

Taken into consideration that physiographic units coincide to great extent with the formed soils, the correlation between physiography and soils could be represented by soil sets and presented as physiographic and soil map, (Fig. 3), the different mapping units and their areas are given in Table 2.
The soils of the investigated area are represented by representative 20 soil profiles cover the different soil variations, the field morphological description of these profiles, and the main physical and chemical characteristics were used to classify the soils to the sub-great group level according to USDA (2010). 
TABLE 2. Physiography and soil map legend

\begin{tabular}{|c|c|c|c|c|}
\hline \multirow{2}{*}{$\begin{array}{c}\text { Mapping } \\
\text { units }\end{array}$} & Physiography & \multirow{2}{|c|}{ Soils } & \multicolumn{2}{|c|}{ Area } \\
\hline P11 & Crest & ------ & 23917.15 & 8.17 \\
\hline P12 & Upland & ----- & 81482.58 & 27.83 \\
\hline P21 & Pediplain & $\begin{array}{c}\text { Typic Torripsamments } \\
\text { Typic Quartzipsamments }\end{array}$ & 68153.74 & 23.28 \\
\hline P 22 & Bajada & Typic Torripsamments & 17193.20 & 5.87 \\
\hline P23 & Wadi & $\begin{array}{r}\text { Typic Torripsamments } \\
\text { Typic Quartzipsamments }\end{array}$ & 102018.7 & 34.85 \\
\hline
\end{tabular}

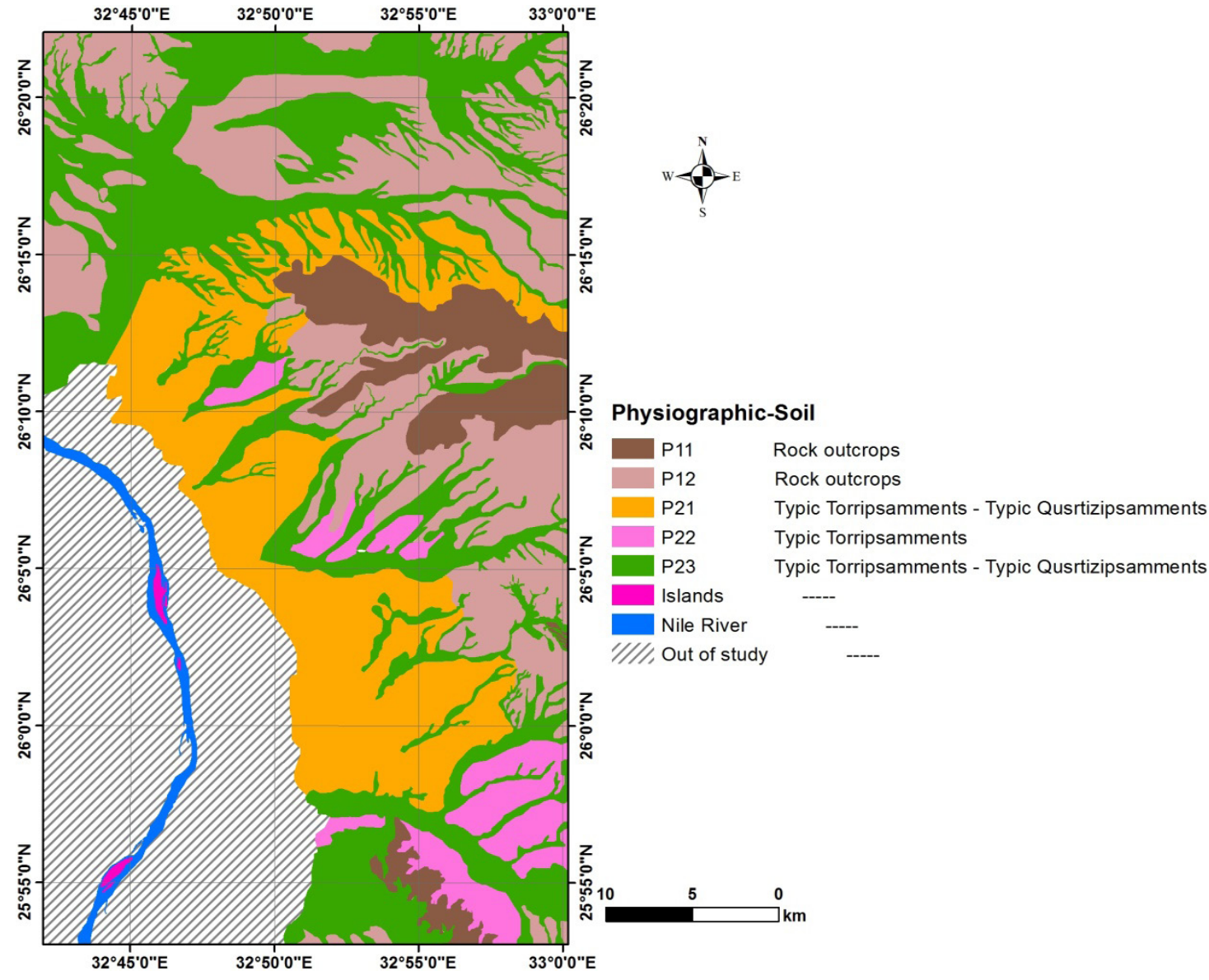

Fig. 3. Physiographic and soil map

\section{Conclusion}

Physiography and soil maps of Wadi Qena Wadi El-Qarn area were produced by using the land surveying, remote sensing data and GIS techniques. The results indicated that the main physiographic units include Crest, Upland, Pediplain, Bajada and Wadis. Soils were classified to Typic Torripsamments and Typic Quartzipsamments. The use of remote sensing and GIS propose an integrated system to Egypt. J. Soil Sci. 57, No. 2 ( 2017 ) quantitative the correlation between physiography and soils.

\section{References}

Abd El-Gaffar, M.K. (1997) Geology of Wadi Qena Downstream Soils and Their Evaluations for some Land Uses, Eastern Desert, Egypt. M.Sc. Thesis, Faculty of Science, Cairo University. 
Aggour, T.A. (1997) Impact of Geomorphological and geological Setting on Groundwater in Qena-Safaga District-Central Eastern Desert-Egypt. Ph.D. Thesis, Faculty of Science, Ain Shams University.

Dobos, E., Norman, B., Bruee, W., Luca, M., Chris, J. and Erika, M. (2002) The Use of DEM and Satellite Images for Regional Scale Soil Database. 17th World Congress of Soil Science (WCSS), 1421- August 2002, Bangkok, Thailand.

Elbersen, G. and Catalan, R. (1986) Portable Computers in Physiographic Soil Survey. Proc. International Soil Sci., Cong. Homburg.

FAO (2006). Guidelines For Soil Description. 4th edition. FAO, Rome, Italy.

Hassan, A.Z. (1984) Pedoechemical studies on some Valies of the Eastern Coast of A.R.E. Ph.D. Thesis, Faculty of Agriculture, Moshtohor, Benha Branch, Zagazig University, Egypt.

Heritage, G.L., Milan, D. J., Large, A.R.G. and Fuller, I.C. (2009) Influence of Survey Strategy and Interpolation Model upon DEM Quality. Geomorphology, 112 ,pp. $334-344$

ITT (2009) ITT Corporation ENVI 4.7 Software. 1133 Westchester Avenue, White Plains, NY 10604, USA.

Lazaridou, M. and Patmios, E. (2002) Image Interpretation (Aerial Photography, Satellite Imagery) On Terrain Analysis and Evaluation, Abstracts of the ISPRS
Commission, VII Symposium on Resource and Environmental Monitoring, Hyderabad, India.

Lillesand, T.M. and Kiefer, R.W (2007) Remote Sensing and Image Interpretation. 5th ed. John Wiley, New York, pp: 820.

Mather, P.M. and Koch, M. (2011) Computer Processing of Remotely-Sensed Images: An Introduction, 4th edition. John Wiley \& Sons, Ltd., Publications, U.K.

Reddy, A.M. (2008) Textbook of Remote Sensing and Geographical Information Systems. Third edition, BS Publications, Hyderabad, India, 476 pp.

USDA (2004) Soil Survey Laboratory Methods Manual Soil Survey Investigation Report No. 42 Version 4.0 November 2004.

USDA (2010) Keys to Soil Taxonomy. United State Department of Agriculture, Natural Resources Conservation Service (NRCS) eleventh edition.

Weng, Q. (2010) Remote Sensing and GIS Integration Theories, Methods, and Applications. The McGrawHill Companies, Inc., 433 pp.

Zinck, J.A. and Valenzuela, C.R (1990) Soil Geographic Database: Structure and Application Examples. ITC journal, 3, 270.

(Received: 27/1/2016; accepted: 1 /2 / 2016)

$$
\begin{aligned}
& \text { عمل خرائط فيزيوجر افية وخرائط تربة لواديى قنا والقرن باستخدام الاستثنعار عن بعد ونظم } \\
& \text { المعلومات الجغر افية } \\
& \text { محمود محمد إبراهيم ، محمد أحمد وهاب *، رأفت رمضان على *، أحمد عبد القتاح البارودى }
\end{aligned}
$$

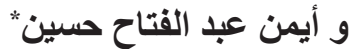

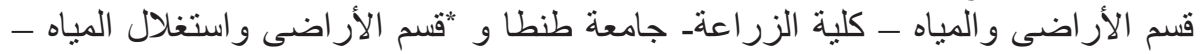

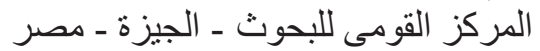

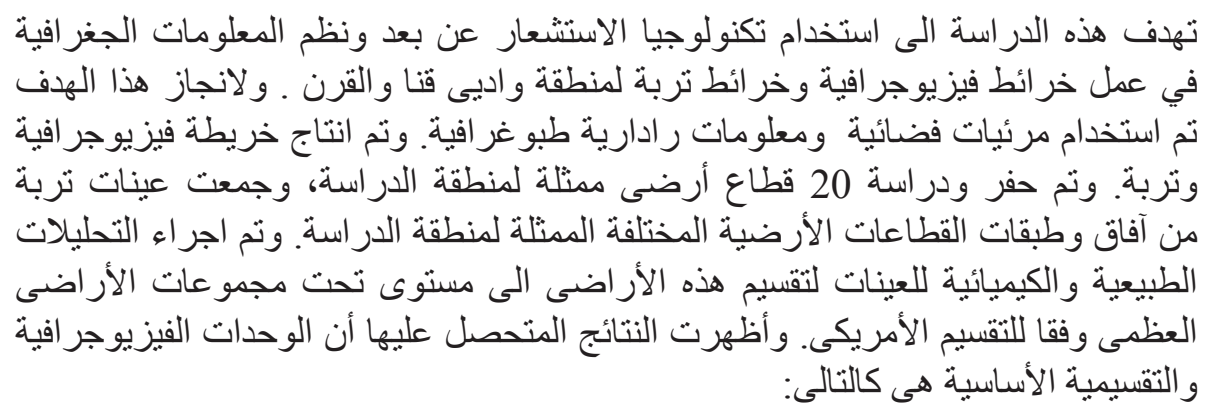

Physiographic Units: Crest, Upland, Pediplain, Bajada and Wadis

Taxonomic Units: TypicTorripsamments and TypicQuartzipsamments

Egypt. J. Soil Sci. 57, No. 2 ( 2017 ) 